\title{
Polarizer Device
}

National Cancer Institute

\section{Source}

National Cancer Institute. Polarizer Device. NCI Thesaurus. Code C50110.

An optical device that creates polarized light from incident light. 